NATALIA GNATIV

National Academy of Agrarian Sciences of Ukraine

Kyiv, Ukraine

\title{
RURAL DEVELOPMENT IN THE CONTEXT OF EUROPEAN INTEGRATION OF UKRAINE
}

\begin{abstract}
The paper describes the key aspects of rural development in Ukraine. Attention is focused on the interpretation of a concept of "rural areas" as an object of scientific research on economy of nature management and environment protection. It substantiates the importance of Ukraine's transition to the sustainable rural development concept. The paper also characterises the advantages and disadvantages of basic components of sustainable rural development: economic, social and ecological. The fundamental problems and factors of present-day unsatisfactory condition of rural development in Ukraine are presented. The usefulness of providing into the following research the normative and legal factors in order to improve state administrative system and management is proved. Prospective directions of Ukrainian government support for sustainable rural development are suggested. European experience of sustainable rural development and possibility of its application in Ukraine is discussed.
\end{abstract}

Key words: competitiveness of agriculture, food industry enterprises, rural areas, rural population, urban population, Stryi district, sustainable rural development, agricultural production, European experience

Due to its favourable geographical conditions, temperate climate and fertile soils Ukraine has traditionally been considered as an agricultural country, as the share of agricultural production in GDP in Ukraine is one of the highest in Europe $(8.2 \%)$. Nominal GDP for the $2^{\text {nd }}$ quarter of 2014 was UAH 372,770 million. Real GDP for the $2^{\text {nd }}$ quarter of 2014 , compared with $2^{\text {nd }}$ quarter of 2013 (at constant prices of 2010), was $95.4 \%$ and compared with the $1^{\text {st }}$ quarter of 2014 , seasonally adjusted $-96.8 \%$ (excluding the temporarily occupied territory of the Autonomous Republic of Crimea and Sevastopol). 
The priority and dominance of agricultural sector caused the appropriate attitude of people to the land, formed special traditions of carrying out personal farming and "culture of behaviour" towards the environment protection. Along with this, what deserves particular attention is the identity of a villager (peasant) as the owner of land plot, who not only has the relevant knowledge and skills of economic activity, but also refers to his work with respect, specifically, his anthropogenic activities, should not lead to soil depletion, water pollution, poor quality of agricultural production, etc.

However, not only peasant, but also other agricultural producers must be responsible for their activities (for example, agricultural cooperatives, farmers, agricultural holdings). And for this purpose suitable conditions for doing business should be created for them. Unfortunately, Ukrainian rural areas have been going through prolonged economic and social crisis, which is the most problematic link of economic activity, especially towards crop and livestock production realisation. In addition, the situation becomes more complicated because living standards in the rural areas continue to be very low.

Decline of rural areas and socio-economic crisis of Ukrainian rural areas are accompanied by a systemic decrease in living standards of rural population and agricultural production decrease.

Successful development of rural areas is a guarantor of food security, its economic independence, investment attractiveness and strong export positions. A village has always been and still is the carrier of historical values, cultural traditions, transformer of mentality and spirituality and national identity.

But because of the scientific and technological revolution and industrial development, innovation in agriculture, intensive production, natural population growth and, on the other hand, destruction of humus layer of the planet, impoverishment of biodiversity, depletion of natural resources, pollution, etc., rural areas, as a separate system of the social structure of society, gradually started to lose their value, which led to numerous degradation processes.

Thus, it is the right time for Ukrainian village to realise the Concept of sustainable development of rural areas. World tendencies show that the development of rural areas should be characterised by the balance of its three main components, namely: economic, social and ecological sustainability.

After the adoption of the Declaration of Independence of Ukraine (August 24,1991 ) and a long period of socio-economic reforms in Ukraine, socio-economic situation and living conditions remain at a low level, particularly in the rural areas. The main problems of rural areas development in Ukraine include:

- unemployment and low level of wages, absence of work motivation;

- demographic crisis;

- internal and external migration;

- unsatisfactory condition of social infrastructure and public services, transport and communication connections; 
- cultural and educational decline;

- unsatisfactory health services;

- inability of comprehensive human development (spiritual, aesthetic, physical, etc.);

- imperfect regulatory and legal framework and lack of well-defined rural development policy and support;

- contamination of the natural environment;

- low level of environmental consciousness and responsibility.

According to the National Rating Agency "Rurik", there are some improvements in the market of agricultural products: in January-September 2013 the index of agricultural production, compared to corresponding period of 2012, increased by $3.0 \%$, including agricultural enterprises - by $1.8 \%$, and households $-3.9 \%$. During the first 9 months the index amount of crop production against the respective period of 2012 amounted to $119.8 \%$, including agrarian enterprises $-133.4 \%$ and households of population $-109.6 \%$ (Fig. 1 Dynamics of agricultural production in $2013, \%)^{1}$.

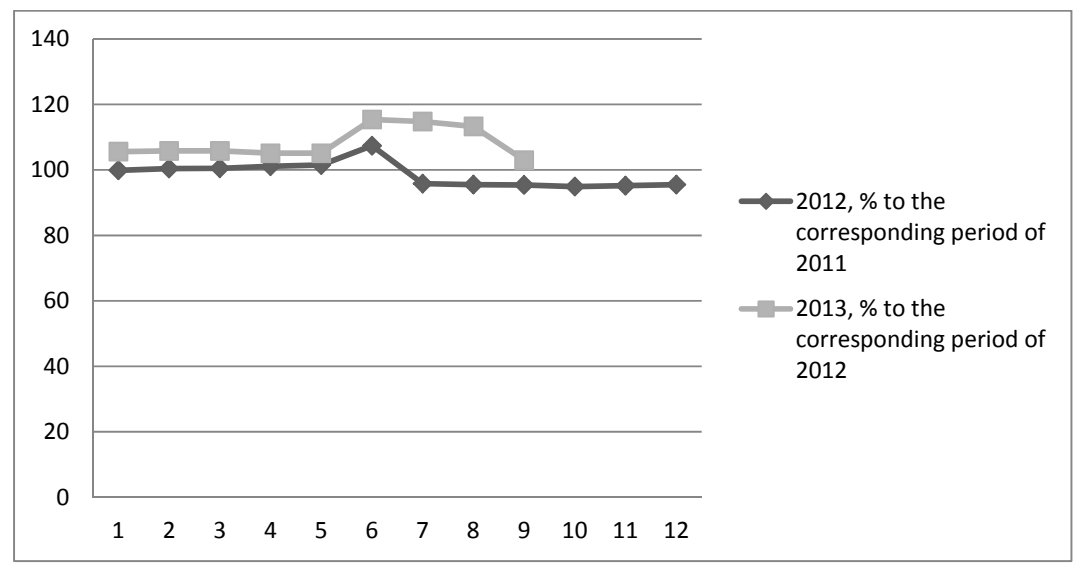

Fig. 1. Dynamics of agricultural production in $2013, \%$

Studying the problems of rural areas development, first of all, it is necessary to define the term "rural areas". Although the term "rural areas" is widely debated, not only among the scientific community and government officials, it still does not have an accurate definition, identification and classification, which is unacceptable for scientific research ${ }^{2}$. Among Ukrainian scientists, who investi-

\footnotetext{
${ }^{1}$ Market overview of Agriculture in Ukraine for the 9 months of 2013. National Rating Agency "Rurik". ${ }^{2}$ H.M. Prytula: European practice of identification and classification of rural areas. Bulletin of Agricultural Science of the Black Sea Region. Issue 3, Mykolayiv, Ukraine, 2011,pp.94-99 [in Ukrainian]. A.I. Pavlov:
} 
gate this issue, it is usual to use a number of synonyms, which causes an ambiguity towards research subject, as each researcher offers his own interpretation of the aforementioned term, for example:

- rural areas,

- rural sellitable areas,

- rural zones,

- rural territories,

- rural settlements,

- village,

- countryside.

The situation is complicated by the fact that there is no unified definition of the term "rural areas" in Ukrainian legislation, which is why in various normative acts this concept is interpreted based on the researched object.

Therefore, in our research we decided to examine the term "rural areas" as an object of scientific research on environmental economics and environmental protection, and on this basis to identify and classify rural areas using the European experience.

To this end, we used Physiocratic approach by which LAND is the only source of the additional value and not just a natural resource or basic means of production. And when we omit the word "rural", the word "area", in the vast majority of encyclopaedic publications, is treated as a "land space limited by boundaries". That is, on the basis of the term "rural areas", the main natural resource - LAND, and its boundaries will be determined by the adjective "rural".

Thus, rural areas are a part of the land space, which is characterised by appropriate boundaries as a result of administrative and territorial division where principal activity is LAND USE.

On the basis of literature review of domestic legislation, rural area is characterised by relevant administrative and territorial boundaries and square, which is outside of urban areas, has low-density settlement, low-rise residential buildings with household plots and small population, where the vast majority of residents are engaged in agriculture and, according to the number of inhabitants, it is divided into large rural settlements (from 2 thousand to 5 thousand or more), medium ( 1 to 2 thousand) and small (up to 1,000 inhabitants).

To our knowledge, the European Commission developed a new urban/rural typology which is based on a classification of grid cells of $1 \mathrm{~km}^{2}$ as either urban or rural. To be considered as urban, grid cells should fulfil two conditions: a population density of at least 300 inhabitants per $\mathrm{km}^{2}$ and a minimum population of 5,000 inhabitants in contiguous cells above the density threshold. The other cells are considered as rural ${ }^{3}$.

Rural areas as object of scientific research. Access: http://nbuv.gov.ua/j-pdf/DeBu_2007_1(1)_6.pdf [in Ukrainian].

${ }^{3}$ Eurostat News Release 51/2012 from 30 March 2012. 
NUTS 3 regions have been classified into three groups based on the classification of these grid cells:

- predominantly urban region: population in grid cells classified as urban make up more than $80 \%$ of the total population;

- intermediate region: population in grid cells classified as urban make up between $50 \%$ and $80 \%$ of the total population (population in rural cells between $20 \%$ and $50 \%$ );

- predominantly rural region: population in grid cells classified as rural make up $50 \%$ or more of the total population.

According to this classification, $41 \%$ of the population of the EU27 lived in urban regions, $35 \%$ in intermediate regions and $23 \%$ in rural regions. In case of Ukraine, as a future EU Member State, it belongs to the intermediate type, because the number of urban population accounts for $69 \%$.

Various programs of national, regional and local level have been developed within the context of popularisation of the ideas of sustainable development in Ukraine. The practice widely used in the EU countries demonstrates the efficiency and effectiveness of its implementation, since to each region an individual approach is applied at the level of vertical and horizontal structures, considering specific climatic and geographical conditions, etc., on the base of which concrete plan of action for a certain period of time is developed ${ }^{4}$.

As the national scientific community has not yet defined the limits of "rural areas", it is advisable to use the experience of European countries and the classification of urban/rural typology. We decided to conduct our research on such three levels - national (by regions of Ukraine), regional (by districts of region), local (by rural areas of district). In this way we want to study to what type (urban, intermediate or rural), exactly, Ukrainian regions, districts and rural areas belong. And on the basis of this to develop a strategy for sustainable rural development adapted to the Ukrainian realities.

We started our research with the comparison of urban and rural population in Ukraine and European countries, and noticed essential differences. Figure 2 and Figure 3 present the statistical distribution of the proportion of urban and rural population in Ukraine and European countries.

Social and economic condition of rural areas of the investigated district is as follows. Actual values of 12 indicators of socio-economic condition of human settlements (population, square of agricultural lands, distance to the district centre, number of pensioners, number of cultural institutions, number of educational institutions, number of infrastructure facilities, number of pupils in school and number of empty households) were considered as random variables to identify possible patterns - interdependence between them (by correlation

\footnotetext{
${ }^{4}$ S.M. Moroz: Changes in rural areas of Ukraine: problems and opportunities. European Association of Agricultural Economists $118^{\text {th }}$ Seminar. 25-27 August 2010, Ljubljana, Slovenia, access: $118^{\text {th }}$ Seminar, 25-27 August, 2010, Ljubljana, Slovenia.
} 
analysis), and through the mechanism of formation of these indicators as a statistical aggregate (by clarifying the kind of distribution laws of them as random variables). At the same time, we take into consideration that some of them are continuous values (square of agricultural lands, distance to the district centre), others - discrete (number of corresponding institutions), and some of them, are essentially discrete (population, number of pensioners).

In the next step of our research we decided to focus on the local level. For this reason we selected representative district of Lviv region and began to analyse the data.

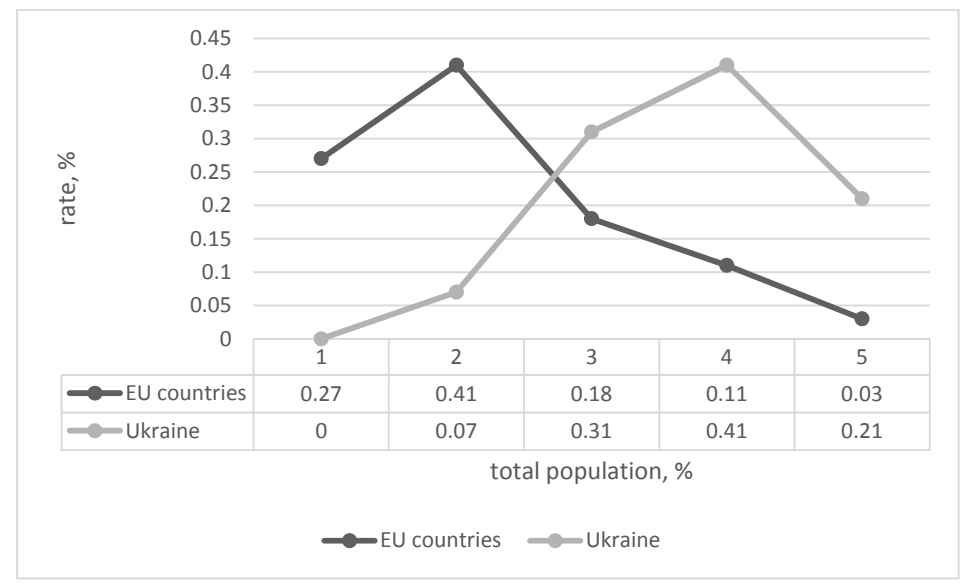

Fig. 2. Statistical distribution of the proportion of urban population in Ukraine and European countries

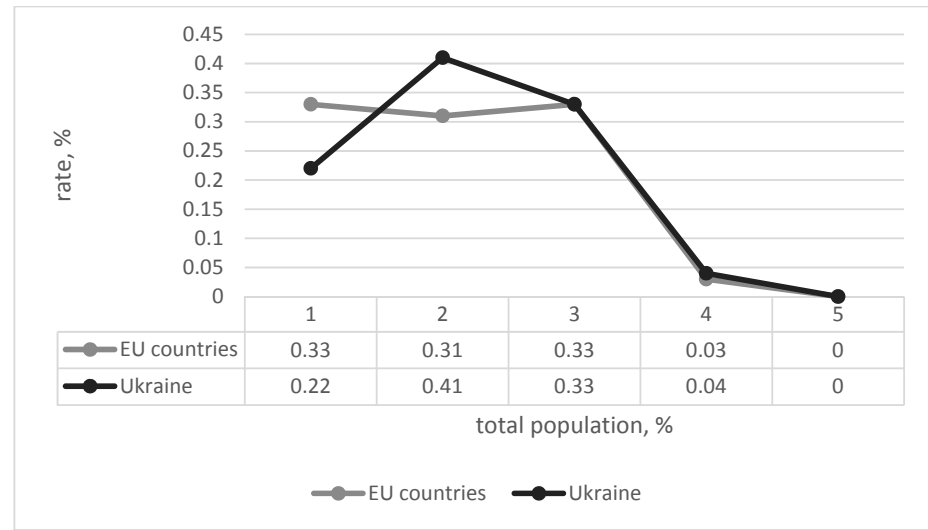

Fig. 3. Statistical distribution of the proportion of rural population in Ukraine and European countries 
Therefore, having the data about rural population, number of empty households and square of agricultural land we have chosen representative for Lviv district - i.e. Stryi district - and described the socio-economic situation in rural areas. For this purpose, on the basis of data on population, number of empty households, distance from the district centre, square of agricultural land, number of cultural and educational institutions, number of pensioners, number of pupils in school, number of infrastructure facilities in all 70 rural areas of Stryi district of Lviv region we found statistical characteristics (simple mean, standard deviation and coefficient of variation) of statistically average (representative) rural area of the district.

According to the results of statistical treatment, an average rural area in the examined district has 248 households, $6 \%$ of which are empty, i.e. nobody lives there. The average rural population is 900 people (30\% of whom are pensioners). The total square of agricultural land occupies 725 hectares. The average distance from the district centre is $12 \mathrm{~km}$ and in each rural area there is one educational and one infrastructure institution. The educational system in rural areas of investigated district is poorly developed, as the share of rural areas where there is not even a primary school is $30 \%$, and only $12 \%$ of rural areas are provided with kindergartens. The average number of pupils who study in school amounts to 103 persons. It should be mentioned that in all rural areas there is at least one religious building (church or chapel) ${ }^{5}$. According to the data graphical interpretation of each of the studied indicators is created. For example, a graphical interpretation of the distribution of empty households in rural areas and square of agricultural land in rural areas is presented below (Fig. 4, Fig. 5).

These distributions differ significantly by type, which may be the object of separate studies. Therefore, the next research is expected to find out the kind of distribution of socio-economic condition. It is also important to detect regularities of these indicators and estimate its connection with GDP values and indicators of agro-ecological condition of rural areas.

Speaking about sustainable rural development, very interesting is an idea of agricultural holdings cooperation with private households of rural population that grow agricultural products for sale. In accordance with legislative framework every 5 years private households of the peasants should be monitored. However, the difficult economic situation and lack of money make it impossible to carry out such investigations, and in some private laboratories such tests are quite expensive and peasants do not have the possibility to verify the correspondence of cultivated agricultural production with the requirements of state standards of quality ${ }^{6}$. Therefore, agricultural holdings could offer such tests of agricultural production to peasants following contractual terms.

\footnotetext{
${ }^{5}$ V. Romanjuk, R. Pastuch: Stryi district. Stryi, Ukraine, 2012, 688 p. [in Ukrainian].

${ }^{6}$ N. Palapa. S. Senchuk: Agroecological peculiarities of agricultural land assessment. Technique and technology of agriculture. No. 2, Lviv, Ukraine, 2011, pp. 36-39 [in Ukrainian].
} 


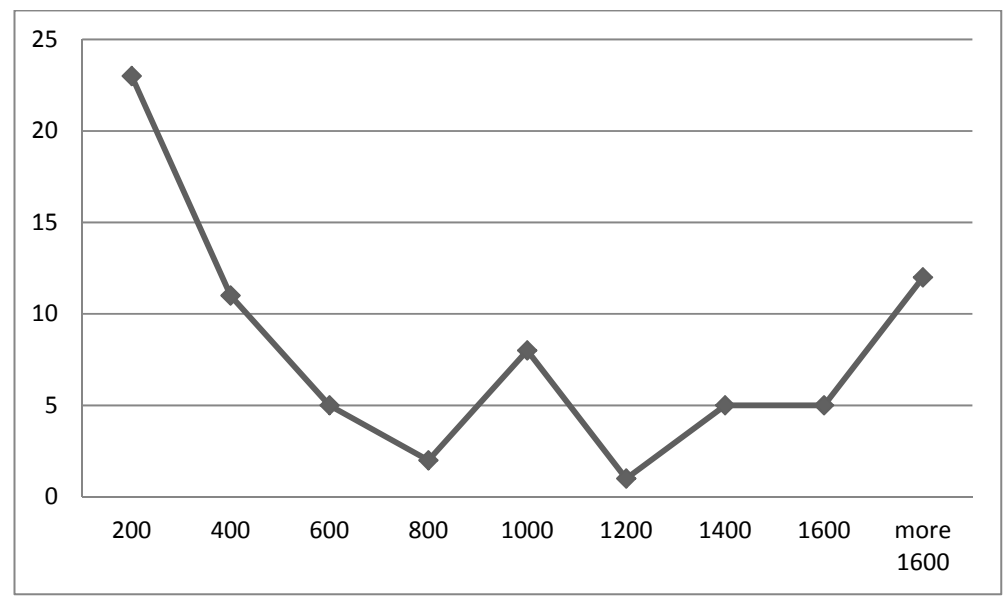

Fig. 4. Statistical distribution of agricultural land in rural areas (Stryi district)

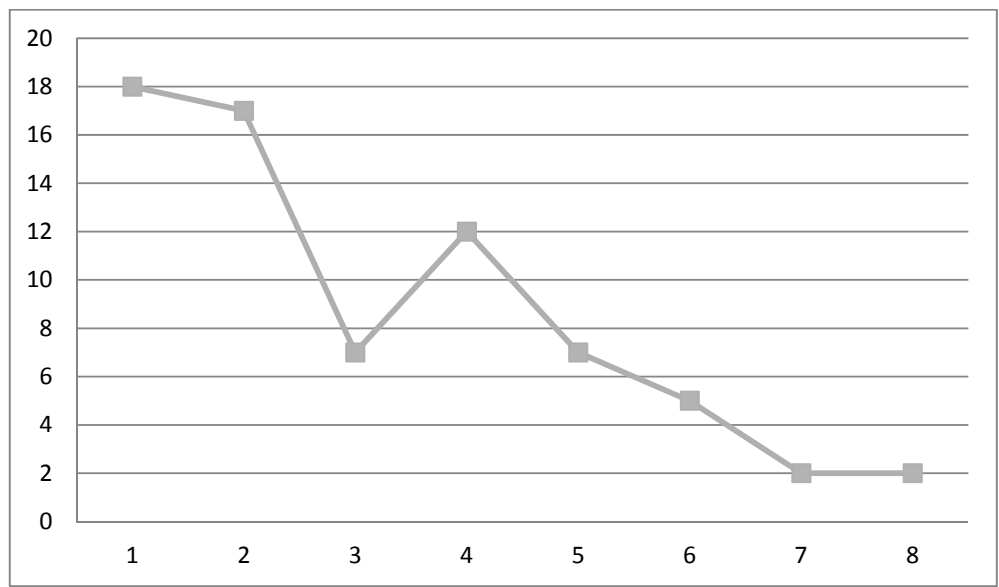

Fig. 5. Statistical distribution of empty households in rural areas (Stryi district)

For example, in 2013 agricultural holding "HarvEast" created a special Agency of Rural Areas Development. The main target of the Agency work is assistance to development of rural areas in Ukraine.

Main areas of activity of the Agency:

- assistance to development of entrepreneurship, small and medium business, creation of conditions for rise in the level of people's employment;

- support of public initiatives, facilitation of rise in social and civil activity of the inhabitants;

${ }^{7}$ Web page of the agricultural holding "HarvEast". Access: http://harveast.com/. 
- encouragement of self-organisation of communities for solving problems of economic, social and cultural development;

- assistance to inhabitants of rural areas in implementation of their own creative, sports, organisational abilities and ensuring the realisation of cultural, public and social interests;

- conduct of investigations, collection and analysis of information about regional problems;

- participation in implementation of regional socio-economic development programs;

- increase in energy effectiveness of rural areas, implementation of energy saving projects for facilities of social and communal infrastructure;

- engagement of rural areas inhabitants in healthy lifestyle;

- organisation and conduct of trainings, cultural and educational, entertainment, training, scientific, health-improving and recreational events;

- establishing cooperation with agencies, organisations, grantors, business representatives and state authorities.

Today, the issues of European integration are topical for the whole social structure of Ukrainian society. These questions are particularly actual in the context of sustainable rural development that provides a harmonious combination and interconditionality of such main components as economic, social and ecological. However, for Ukraine, at this stage of integration with the EU structure, it is especially important to develop its own strategy of advancing rural development (in opposition to "catch-up modernisation strategy"8) given the characteristics of economic activities, social relations, and economic situation, etc.

For this purpose, first of all, it is necessary to modernise normative and legislative framework that would allow rural population to ensure successful housekeeping and, due to favourable conditions, realise agricultural products under the system of privileges and subsidies. It is also important to support small agribusiness and medium-sized agribusiness through the creation of advantageous basis for cooperative farms. With regard to powerful agricultural enterprises (agroholdings), it is advisable due to their payments to fill local budgets in order to improve social infrastructure of rural areas as well as oblige renters to carry out annual monitoring of the environment in connection with their production activities, and in the case of harmful impact on natural resources, it is necessary to develop new technologies and innovative methods to improve agroecological condition of rural areas.

Thus, the main factors of unsatisfactory condition of rural areas are socio-economic difficulties, absence of state control, unsatisfactory legal framework and lack of scientifically justified recommendations for agricultural production in private households. So peasants cultivate the land, follow crop rotation, use

\footnotetext{
${ }^{8}$ V. Pasichnyk: Social and economic component of European integration strategy of Ukraine. Academic papers collection. Issue 5, Lviv, Ukraine, 2010 [in Ukrainian].
} 
chemical and mineral fertilisers, etc., with the help of those methods and skills that historically formed in their village and were handed down from generation to generation. Furthermore, peasants are unable to use innovative technologies for farming because of low awareness on how to do it and the shortage of money. Unproductive manual labour still dominates in private agricultural sector in comparison with mechanisation of agriculture production in agri-enterprises, which could not only save time and resources, but also make it possible to get much more profit. Topical problem is the realisation of cultivated agricultural products and utilisation of agricultural waste. That is why, in order for successful Ukrainian rural areas integration into European community we need to solve these problems immediately.

\section{Literature:}

1. Eurostat News Release 51/2012 from 30 March 2012.

2. Market overview of Agriculture in Ukraine for the 9 months of 2013. National Rating Agency "Rurik".

3. Moroz S.M.: Changes in rural areas of Ukraine: problems and opportunities. European Association of Agricultural Economists 118 ${ }^{\text {th }}$ Seminar. 25-27 August, 2010, Ljubljana, Slovenia, access: $118^{\text {th }}$ Seminar, 25-27 August, 2010, Ljubljana, Slovenia.

4. Palapa N., Senchuk S.: Agroecological peculiarities of agricultural land assessment. Technique and technology of agriculture. No.2, Lviv, Ukraine, 2011, pp. 36-39 (in Ukrainian).

5. Pasichnyk V.: Social and economic component of European integration strategy of Ukraine. Academic papers collection. Issue 5, Lviv, Ukraine, 2010 (in Ukrainian).

6. Pavlov A.I.: Rural areas as object of scientific research. Access: http://nbuv.gov.ua/j-pdf/ DeBu_2007_1(1)_6.pdf (in Ukrainian).

7. Prytula H.M.: European practice of identification and classification of rural areas. Bulletin of Agricultural Science of the Black Sea Region. Issue 3, Mykolayiv, Ukraine, 2011, pp. $94-99$ (in Ukrainian).

8. Romanjuk V., Pastuch R.: Stryi district. Stryi, Ukraine, 2012, 688 p. (in Ukrainian).

9. Rural realities in the European Union. Access: http://ec.europa.eu/agriculture/envir/report/en/rur_en/report_en.htm.

10. Web page of the agricultural holding "HarvEast". Access: http://harveast.com/. 
OREST FURDYCHKO

NATALIA GNATIV

Narodowa Akademia Nauk Rolniczych Ukrainy

Kijów, Ukraina

\title{
ROZWÓJ OBSZARÓW WIEJSKICH W KONTEKŚCIE INTEGRACJI EUROPEJSKIEJ UKRAINY
}

\begin{abstract}
Abstrakt
Artykut poświęcony jest najważniejszym aspektom rozwoju obszarów wiejskich na Ukrainie. Uwage skupiono głównie na interpretacji koncepcji „obszarów wiejskich” jako przedmiotu badań naukowych dotyczacych ekonomii zarzadzania środowiskiem i ochrony przyrody. Uzasadniono również znaczenie przejścia Ukrainy na koncepcje zrównoważonego rozwoju obszarów wiejskich. Opisano wady i zalety podstawowych składowych zrównoważonego rozwoju obszarów wiejskich, takich jak elementy gospodarcze, społeczne i ekologiczne. Przedstawiono również najważniejsze problemy i bariery hamujace rozwój obszarów wiejskich na Ukrainie. Artykut prezentuje również dowody na przydatność czynników normatywnych i prawnych wykorzystanych $w$ badaniu, $w$ celu poprawy stanu systemu administracyjnego i zarzadzania. Sugeruje potencjalne kierunki wsparcia zrównoważonego rozwoju obszarów wiejskich przez rzad ukraiński i omawia europejskie doświadczenia $w$ zakresie zrównoważonego rozwoju obszarów wiejskich oraz możliwości ich wykorzystania na gruncie ukraińskim.
\end{abstract}

Słowa kluczowe: konkurencyjność rolnictwa, przedsiębiorstwa przemysłu spożywczego, obszary wiejskie, ludność wiejska, ludność miejska, rejon stryjski, produkcja rolna, doświadczenia europejskie

Zaakceptowano do druku - Accepted for print: 28.08.2015. 